\title{
City greening by rain gardens - costs and benefits
}

* Institute of Environmental Protection - National Research Institute, Poland,

* Vista Analyse,

*** Vista Analyse and Business School, Oslo Metropolitan University;

e-mail: ewelina.siwiec@ios.gov.pl

Keywords:

green areas, rain gardens, adaptation to climate change, costs, benefits, Poland

\section{Abstract}

In urban areas, the most pressing adaptation challenges are associated with the problem of poor retention of rainstorm water. Hence, recommended actions focus on improving rainwater retention in the landscape. One of the strategic direction of adaptation to climate change is including green infrastructure solutions like green roofs, green walls, water reservoirs along streets - supplying high vegetation, permeable ground cover and rain gardens. Due to a variety of proposals, the costs and benefits resulting from the implementation of a chosen solution should be regarded when selecting an appropriate action. Considering the above, the article attempts to show the costs and benefits of one of the solutions - a green garden. When analysing the cost of green garden implementation, account should be taken of the cost of investment and upholding, as well as the alternative cost of land use. Then again, the benefits of the rain garden comprise the losses avoided by limiting the effects of rainstorm as well as improving the quality and quantity of water in the urban landscape. The cost and benefit monetization makes it possible to decide on the financial viability of implementing rain gardens in the city.

c IOŚ-PIB

\section{INTRODUCTION}

Cities are particularly sensitive to climate change. For example, in Poland, more than $60 \%$ of the country's population live in cities [Podręcznik adaptacji dla miast - Urban Adaptation Handbook, 2015] The most pressing adaptation challenges in cities are associated with problems, such as the urban heat island and low retention of rainstorm water. Urban areas are flooded as a result of their progressive development [Bolund, Hunhammar 1999]. Inadequate drainage systems are not sufficient enough to receive all runoff after intense raining or snow melting. Besides, reduction of ground permeability impedes groundwater supply, and this lowers the groundwater table level, followed by water shortages. Another issue associated with city water management is limited biological water purification on account of removal of biogenic compounds by plants [Kosmala, 2003]. Recognizing the severity of climate change impacts, Poland's five medium size cities, that is, Nowy Sącz, Tomaszów Mazowiecki, Ostrołęka, Siedlce and Bełchatów, joined the project Climcities, in the framework of which, draft climate change adaptation strategies were prepared for the above partner cities. ${ }^{1}$

1 The cities of Ostrołęka, Bełchatów, Nowy Sącz, Tomaszów Mazowiecki and Siedlce are partners of the Institute of Environmental Protection - National Research Institute in the project 'Climate change
Recommended adaptation measures for the cities focus on improving rainwater retention by including green infrastructure solutions. These solutions include green roofs, green walls, small water reservoirs along streets supplying high vegetation, permeable ground cover and rain gardens. Due to a variety of proposals, the choice of the right design solution should take into account both its costs and the benefits of its implementation. Considering the above, the article deals with the issues of costs and benefits of the design solution such as the rain garden, proposed in climate change adaptation strategies prepared for the partner cities.

\section{GREEN AREAS IN CITIES}

Green areas improve the life comfort of city residents directly and indirectly. Plants uptake water from the soil, transport it up to their branches and leaves, and then release in the process of evapotranspiration [Suchocka 2011]. As a

adaptation in small and medium size cities', co-financed by the EEA Financial Mechanism 2009-2014, under the Bilateral Cooperation Fund, and realized by the Institute in cooperation with the Norwegian Partner Vista Analyse, based on the agreement with the National Fund for Environmental Protection and Water Management. 
result, plants become temporary water reservoirs involved in slow water release. According to the Federal Interagency Stream Restoration Working Group (FISRWG), in urban areas with deficient vegetation cover and limited permeable areas, just about $55 \%$ of precipitation is drained by the rainwater drainage system. ${ }^{2}$ In contrast, within the city areas with natural ground surface cover, approximately $10 \%$ of precipitation is discharged into the drainage. The remaining rainfall water is absorbed by the soil or is evaporated by vegetation. Accordingly, urban greenery reduces the effects of rainstorms and flooding. Furthermore, green areas improve thermal comfort during hot days and increase air humidity, which helps to alleviate effects of the urban heat island. In periods of heat wave, temperature in suburban forests can be as much as $12^{\circ} \mathrm{C}$ lower, when compared to the city centre [Wagner et al. 2013]. Consequently, urban greenery not only prevents flooding, but also mitigates microclimate and improves the life comfort of urban society. The most commonly used indicator to assess a level of greening is the share of parks, and other green areas in the city area. Among the partner cities in the framework of Climcities, the highest share of parks and urban green areas is in the city of Ostrołęka (index value $4.3 \%$ ), and the lowest - in Nowy Sącz (1.6\%). In the period from 2014 to 2016, the index value increased slightly in the case of Nowy Sącz and Tomaszow Mazowiecki, while in Ostrołęka and Bełchatów, the index value decreased. A detailed comparison of the index values for partner cities is presented in Table 1.

In Poland, according to MojaPolis and BIQdata (2015), the most green city is Chorzów with the highest greenery index of $22.2 \%$. The next in the order are the cities Siemianowice Sląskie with the index value $9 \%$ and Bydgoszcz having the index value over $8 \%$. The low index values obtained for urban green areas and data on further damage caused by rainstorms and flooding indicate that the potential of green areas is not fully utilized in the partner cities.

Green measures can reduce the pressure on the drainage system in cities by infiltrating or retaining water during the peak of rainstorms. The suitability of the different measures will depend on the local conditions of the area. Firstly, the measures vary in their capacity to infiltrate/retain runoff and so, it is necessary to analyse the extra capacity needed in the area to reduce the risk of future floods. Secondly, the costs of implementing different measures vary with conditions such as the type of ground cover and terrain, the value of the land, and the characteristics of the built environment in the area. Green measures comprise green roofs, open streams, ponds, wetlands as well as rain gardens

\section{RAIN GARDENS AS A WAY OF GREENING CITIES}

The rain garden is an area planted with native plant species, located in the ground or in a container, most often in the

2 Based on the assumption that there is $75-100 \%$ impermeable ground cover.
Table 1. The share of parks, green areas and green spaces in the Climcities partner cities in \%.

\begin{tabular}{|l|l|l|l|}
\hline \multicolumn{1}{|c|}{2014} & 2015 & 2016 \\
\hline Nowy Sącz & 1.6 & 1.9 & 1.9 \\
\hline Siedlce & 3.3 & 3.1 & 3.3 \\
\hline Tomaszów Mazowiecki & 2.4 & 2.5 & 2.6 \\
\hline Ostrołęka & 4.3 & 4.3 & 4.1 \\
\hline Bełchatów & 2.4 & 2.3 & 2.2 \\
\hline
\end{tabular}

Source: Own development; based on the Local Data Bank

vicinity of storm sewers [Długozima 2009, Śmietańska 2012, Domanowska, Kostecki 2015]. Properly selected plants eliminate pollutants from rainwater flowing down from city streets, squares and roofs [Śmietańska 2012] and limit the discharge of water from impermeable surfaces to the sewage system [Domanowska Kostecki 2015]. These also increase water retention, which is of great importance in the context of adaptation to climate change and the reduction of damage caused by intense rains. Below photo one of the first rain garden in Poland (Photo 1).

Rain gardens are also characterized by a specially designed structure of the substrate (medium) filtrating rainwater, which holds back runoff flow into the drainage system and gradually infiltrates water to the ground. According to the Low Density Residential Bioretention, rain gardens retain in the ground about 30\% more water than lawns [Kosmala 2003].

\section{RAIN GARDEN COSTS AND BENEFITS}

Adaptive solutions such as rain gardens should be viewed in the context of costs and benefits of their implementation. A detailed summary of costs and benefits is presented in Table 2.

The cost of implementing a rain garden depends on several factors, including its size, soil conditions, location, design, time of implementation and the types of plants and materials used. The costs of rain gardens can be categorised into investment costs, operation and maintenance costs, and the opportunity cost of land use. Information about costs of rain gardens in Poland is limited. According to the Fundacja Sendzimira, the total cost of rain gardens is about 2,000-2,500 PLN per $2 \mathrm{~m}^{2}$. Nevertheless, for specific installations of rain gardens being considered, the responsible firm should be able to provide an estimate of the costs required for the investment and operation/ 


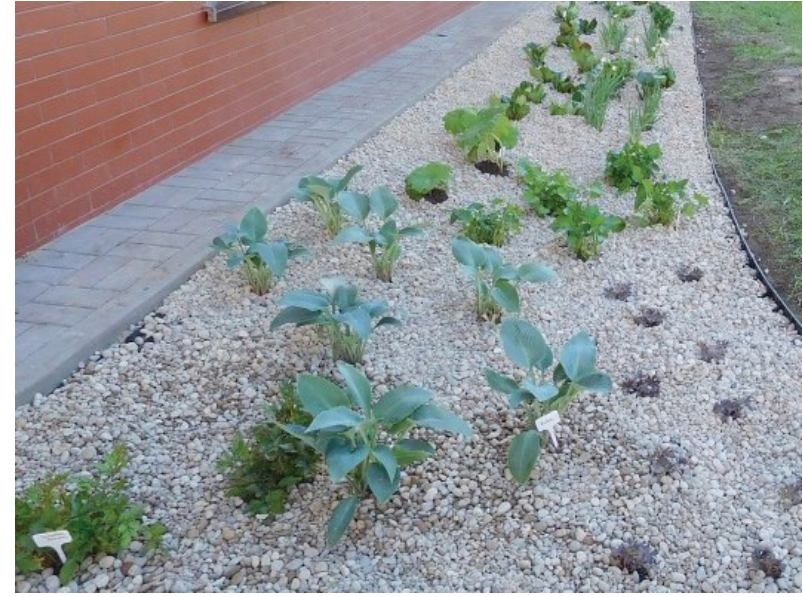

Photo 1. One of the first rain garden in Poland (Marki). Source: Fundacja Sendzimira

Table 2. Rain garden costs and benefits.

\begin{tabular}{|c|c|}
\hline Costs & Benefits \\
\hline $\begin{array}{l}\text { - Investment costs } \\
\text { - Operation and } \\
\text { maintenance cost } \\
\text { Opportunity cost of } \\
\text { land use }\end{array}$ & $\begin{array}{ll}\text { - } & \text { Avoided damage } \\
\text { - Water quality } \\
\text { control } \\
\text { - Water quantity } \\
\text { control } \\
\text { - Co-benefits }\end{array}$ \\
\hline
\end{tabular}

Source: Own development

maintenance of their proposed rain garden. According to the Minnesota Stormwater Manual, the surface area of a rain garden should be $5-10 \%$ of the area from which it infiltrates stormwater runoff [MPCA 2008]. In addition to the size of the runoff-area, the infiltration capacity of the filtering layer, the intensity and duration of precipitation and local requirements to the maximum allowed amount of runoff into the sewerage system or streams determine the appropriate size of a garden bed [Paus and Braskerud 2013]. Rain gardens that require drainage are generally more expensive than rain gardens where the soil at the location can be used as filter medium. This will depend on the ability of the local soil to infiltrate water. Clay soil is generally unsuited for infiltration and rain gardens implemented in the areas with clay soils will always need drainage [Paus and Braskerud 2013]. Costs related to the operation and maintenance of rain gardens depend on a range of different factors, for example, a necessity to replace the soil underneath and the type of vegetation used.

Upkeeping the rain garden is important after it has been created to ensure that vegetation is established. Once vegetation is established, the need for maintenance is similar to that of parks with watering during dry periods, mechanical weed control and fertilisation as needed.
Slurry on the filter surface may also need to be removed [Vista Analyse 2015]. It follows that if the rain garden is implemented in a park it would be reasonable to assume that the rain garden would not require additional operation and maintenance cost above what is needed to maintain the park.

The implementation of a rain garden will require some area of land. This has a cost because the area could be used for something else if the rain garden is not implemented. A relevant question then is: What is the value of this area of land in its best alternative use? To answer this question in practice, one can generally look at what the area would have been used for in the absence of the rain garden. If the rain garden was implemented on a vacant block that otherwise could have been used to build properties, a reasonable measure of the opportunity cost of the land use could be the average land value (per $\mathrm{m}^{2}$ ) in the area. However, if the rain garden is implemented in a park where the current use of land is very similar to that of the rain garden (vegetative cover), one could assume that there is no opportunity cost incurred from the implementation of the rain garden. An important benefit of investing in the rain garden is the avoided damage from future floods. The expected avoided damage is calculated as the difference between the expected damage with and without adaptation. The alternative scenario (rain garden implementation) would presumably have lower costs associated with damage from floods, compared to the baseline scenario, depending on the capacity of the rain garden to absorb and delay the flow of water, and this translates into flood risk reduction. Additionally, the potential damage from floods would also depend on the rain garden's ability to avoid contamination of water bodies. The difference in damage cost between the alternative scenario and the baseline scenario may amount to the full amount or a portion of the damage cost. The below sections describe factors impacting a rain garden's ability to control the quantity and quality of stormwater runoff. A rain garden's ability to control the quantity of water depends on its capacity to infiltrate water as well as its ability to delay the flow of water entering the drainage system. A rain garden with underdrain - leading water to the drainage system - infiltrates less water than a rain garden with no underdrain [MPCA 2008]. The latter allows water to infiltrate to the ground and is also better suited to restore groundwater supplies. Whether drainage is necessary depends on the properties of the local soil. For example, drainage is needed in the areas with clay soil.

The capacity of a rain garden to infiltrate water is a complex process influenced by the initial water content of the bioretention media, the capillary suction, and the pressure head from the ponded water [Paus et al. 2016]. They find that the infiltration capacity can be reasonably predicted, based on the following parameters:

- Surface area

- The value for saturated hydraulic conductivity of the of the bioretention media

- The maximum level of water on the surface 
Higher levels of the above factors would result in a higher fraction of runoff infiltrated. Also, site-specific properties such as catchment size and slope, surface types, and the time of concentration have large impacts on the infiltration capacity [Paus et al. 2016]. Stormwater runoff carries various pollutants such as oil, fertilisers, pesticides, sediment and chemicals [Riverlink no date]. If left untreated, stormwater runoff could contaminate streams, rivers and lakes as well as potentially affect recreational activities, such as swimming and fishing, injure aquatic plants and animals and contaminate drinking water.

A rain garden can improve the water quality by filtering pollutants from stormwater runoff. Particles in stormwater are withheld via sedimentation on the surface of the rain garden and filtration through a filter medium. The effect from sedimentation can be increased by ensuring slow inflows of water into the rain garden. The filter medium's ability to filter pollutants depends largely on its grain distribution properties. The properties of the filter medium also determine the type of pollutants that can be withheld [Paus 2016]. According to Paus [2016], a rain garden could reduce:

- particles by around $90 \%$

- oil by around $90 \%$

- $\quad$ dissolved heavy metals (Cd. Cu. Pb. Zn) by around 80$90 \%$

- PAHs (Polycyclic Aromatic Hydrocarbons) by around 70-90\%

- phosphate by around $63 \%$

The benefits of the reduction of pollutants depend on where these pollutants would have ended up in the absence of the rain garden and the impact this could have on humans and aquatic life.
The plants and vegetation of rain gardens can provide ancillary benefits (co-benefits) in addition to the primary purposes of stormwater quantity and quality control. These co-benefits include;

- noise reduction

- improved air quality

- CO2 capture and storage

- local climate control

- biodiversity

- pollination

- visual amenity

- restoration of groundwater supply

The degree to which these co-benefits are realized, and their significance will depend on several factors, including the size of green area provided by the rain gardens.

\section{SUMMARY AND CONCLUSIONS}

The potential of green areas in the cities is not fully utilized. Therefore, the recommended adaptation measures focus on expanding urban green areas through a variety of design solutions (green roofs, green walls, water retention reservoirs, etc.). The rain garden gaining popularity worldwide is one of the solutions. When analysing rain garden implementation costs, account should be taken of investment and maintenance costs, as well as the cost of alternative land use. On the other hand, however, the benefits of the implementation of rain gardens include losses avoided by limiting the effects of rainstorm and improving the quality and quantity of water in the urban landscape. The cost and benefit monetization makes it possible to decide on the financial viability of implementing rain gardens in urban area.

\section{REFERENCES}

Bank Danych Lokalnych.https://bdl.stat.gov.pl/BDL/start [Accessed 10.10.2017]

BOLUND P., HUNHAMMAR S. 1999. Ecosystem services in urban areas. Ecological Economics. 2: 293-301.

DŁUGOZIMA A. 2009 Ogrody deszczowe. Problemy Ekologii; vol 13. $\mathrm{nr} 4$

DOMANOWSKA M., KOSTECKI J. Ogrody deszczowe w miastach jako jedno z narzędzi wdrażania usług ekosystemowych Inżynieria Środowiska. Zeszyty Naukowe. Uniwersytet Zielonogórski. nr 158.38.

FEDERAL INTERAGENCY STREAM RESTORATION WORKING GROUP (FISRWG) (1998). Stream Corridor Restoration: Principles. Processes. and Practices. Revised August 2001. GPO Item No. 0120-A; SuDocs No. A 57.6/2:EN3/ PT.653.ISBN-0-934213-59-3.

FUNDACJA SENDZIMIRA http://sendzimir.org.pl/ [Accesses 10.10. 2017]
KOSMALA M., 2003. Woda w przestrzeni przyrodniczej i kulturowej. Prace Komisji Krajobrazu Kulturowego. T. II. Komisja Krajobrazu Kulturowego PTG. Oddział Katowicki PTG. Sosnowiec

MINNESOTA POLLUTION CONTROL AGENCY (MPCA), 2008. Minnesota Stormwater Manual. St. Paul. Minnesota. USA. https://stormwater.pca.state.mn.us/index. php?title=Main_Page [Accessed 02.10.2017]

MOJAPOLIS. BIQDATA. 2015. http://biqdata.wyborcza. $\mathrm{pl} / \mathrm{sprawdz-czy-twoje-miasto-jest-naprawde-zieolne}$ [Accessed 17.10.2017]

PAUS. K. H., BRASKERUD B. C., 2013. Forslag til dimensjonering og utforming av regnbed for norske forhold. ('Suggestions for dimensioning and design of rain gardens for Norwegian conditions') Vann. 01. 2013. http://dagvattenguiden. se/wp-content/uploads/2013/04/Paus-og-Braskerud_ Forslag-til-dim-og-form-av-regnbed_Vann1-2013.pdf [Accessed 1.10. 2017] 
PAUS K. H., MUTHANNA T. M., BRASKERUD B. C. 2016. The hydrological performance of bioretention cells in regions with cold climates: seasonal variation and implications for design. Hydrology Research. 47.2, 291304.

PAUS. K. H., 2016. Regnbed som renseløsning for forurenset vann ('Rain gardens as cleaning solution for polluted water'). In Norwegian. January 2016. version 1.0. Available from: http://dagvattenguiden.se/wpcontent/uploads/2016/06/Overvann-Regnbed-somrenselosning.pdf [Accessed 02.10.2017].

PODRĘCZNIK ADAPTACJI DLA MIAST. 2015. Ministerstwo Środowiska

RIVERLINK no date. Stormwater Problems \& Impacts: Why All The Fuss? Available from: http://riverlink.org/ wpcontent/uploads/2014/01/stormwaterseriesfinal 1 . pdf [Accessed 8.10. 2017]
SUCHOCKA M. 2011.Wpływ zmiany warunków siedliskowych na stan drzewostanu na terenach inwestycji. Człowiek i Środowisko. 35(1-2); s. 73-91.

ŚMIETAŃSKA M., 2012. Program '10 000 ogrodów deszczowych?'.Zrównoważony Rozwój - Zastosowania nr 3. Fundacja Sendzimira. s. 121

VISTA ANALYSE. COWI. 2015Kostnader og nytte ved overvannstiltak ('Costs and benefits of surface water measures'). In Norwegian. Report number 2015/02.

WAGNER I., KRAUZE K., ZALEWSKI M. 2013.Błękitne aspekty zielonej infrastruktury. Zrównoważony Rozwój - Zastosowania. Nr 4. Katedra Ekologii Stosowanej. Uniwersytet Łódzki. Europejskie Regionalne Centrum Ekohydrologii pod auspicjami UNESCO. Polska Akademia Nauk 